\title{
Utilization Pattern of Khurasani Crop (Guizotia abyssinica) by the Khurasani Growers of Palghar District of Maharashtra, India
}

\author{
Rohit Shelar $^{1 *}$, Himadri Roy ${ }^{1}$, Neha Kale ${ }^{2}$ and D.P. Hardikar ${ }^{3}$ \\ ${ }^{1}$ Department of Extension Education, IAS, BHU, Varanasi, Uttar Pradesh \\ ${ }^{2}$ Department of Extension Education, College of Agriculture, VNKV Parbhani, Maharashtra \\ ${ }^{3}$ ATIC manager, Dr. Balasaheb Sawant Konkan Krishi Vidyapeeth, Dapoli, Maharashtra \\ *Corresponding author
}

\section{A B S T R A C T}

\section{Keywords}

Utilization,

Khurasani growers, Indigenous, Oilseed crop, Palghar district

Article Info

Accepted:

12 July 2018

Available Online:

10 August 2018
Khurasani (Guizotia abyssinica spp.) is considered as an important traditional minor oil seed crop in India, which is mainly cultivated in hilly and tribal areas. Though the crop has high oil content and wide range of utility, very less attention is being paid towards the judicial utilization of the crop by the growers. So, considering this fact the present research work was carried out in Jawhar and Mokhada tahsils of Palghar district of Konkan region of Maharashtra state to know the utilization pattern of Khurasani crop by the growers. The sample was constituted 150 Khurasani growers drawn from two Tahsils. The exploratory research design was used for the present study and the respondents were interviewed with the help of a semi-structured interview schedule. The findings of the research revealed that major portion of produced Khurasani crop (93.90\%) was used for oil extraction purpose. More than half of the $(52.50 \%)$ the extracted oil was used for home consumption purpose. It was also found that majority of the respondents $(79.34 \%)$ gave all the by-products to the mill owners after oil extraction.

\section{Introduction}

Khurasani (Guizotia abyssinica spp.) is an important traditional oilseed crop cultivated mainly in Ethiopia and India. The genus Guizotia consists of six species, of which five, including Khurasani, are native to the Ethiopian highlands. The species constitutes approximately 50 per cent of Ethiopian and 3 per cent of Indian oilseed production. Besides Ethiopia and India, the Food and Agriculture Organization reported that, other production areas include Nepal, Myanmar, Bangladesh and several countries in eastern and central Africa. Khurasani seeds are exported as bird food, mainly to the United States and Europe. Ethiopian Khurasani is reported to be grown mainly in mid-altitude and high area (1600$2200 \mathrm{~m}$ elevation) but also in lower and higher elevations with enough rainfall. In India, rainfall between $1000-1300 \mathrm{~mm}$ is optimal for its production, although well distributed rainfall of $800 \mathrm{~mm}$ can produce reasonable yield (Burnette, 2010). 
It is recognized by various names like Noog in Ethiopia and Rantil, Kalatil, Karala, etc. in India. It is considered as minor oilseed crop but it very important in terms of its oil content, quality and potentiality. The important feature of this crop is that it gives reasonable seed yield even under poor marginal growing conditions. The crop is mainly grown for seed production and oil extraction purpose. The oil is used for culinary purpose, for anointing the body, manufacturing paints and soft soaps, lightening and lubrication purpose and also in cosmetics. The oil cake is well known as cattle feed. The crop sheds a large quantity of dry leaves in the field and thereby adds organic matter to the soil (Talathi et al., 2007).

Khurasani seeds contain around 40 per cent oil and about 20 per cent protein. Oil contains linoleic acid as the primary fatty acids (75$80 \%$ ), followed by palmitic and stearic acid (7-8\%) and oleic acid (5-8\%). Although Indian Khurasani oil is reported higher in oleic acid (25\%) and lower in linoleic acid (55\%). Described as having "nutty taste and pleasant odour," the edible oil is the main product from Khurasani seeds in both Ethiopia and India (Burnette, 2010).

India is considered to be the major Khurasani producing country in the World with an area of 3.64 lakh hectares with the production of 0.98 lakh tonnes and average seed yield of 269 kg per hectare (Anonymous, 2011).

In India it is mainly cultivated in tribal pockets of Madhya Pradesh, Orissa, Maharashtra, Karnataka, Bihar, Andhra Pradesh and West Bengal. Khurasani although considered as a minor oil seed, is very important in terms of quality and taste of its oil and export potentials. This crop can withstand adverse climatic and poor soil conditions.

In Maharashtra, Khurasani is grown over an area of 0.37 lakh hectares with annual production of 0.12 lakh tonnes and seed yield of $324 \mathrm{~kg}$ per hectare (Anonymous, 2011). The major Khurasani growing districts in Maharashtra are Nashik, Osmanabad, Latur, Nanded, Beed, Kolhapur, Pune, Dhule, Ratnagiri and Palghar.

In Konkan region tribal farmers especially those from hilly area of Palghar district used to cultivate Khurasani crop on a large scale. It is an important secondary oilseed crop cultivated by the tribal farmers from Jawhar and Mokhada tahsils of Palghar district.

\section{Materials and Methods}

Present study was conducted in Palghar district of Konkan region of Maharashtra state. The Konkan region of Maharashtra state comprises of five districts. Among those Palghar district was selected purposively for this investigation because of having maximum area under Khurasani cultivation. Again from Palghar district Jawhar and Mokhada tahsils were selected purposively because these two tehsils accounts for the maximum area under Khurasani cultivation. Now, from each selected tahsil five villages were selected randomly. Further the list of Khurasani growers was obtained from KVK for each selected village and 15 Khurasani growers having maximum area under Khurasani cultivation was selected as respondent for the present study.

Thus, in total 150 Khurasani growers were considered as the sample respondents. The exploratory research design was used for the present study and the respondents were interviewed with the help of a semi-structured interview schedule. For this study respondents were asked individually about the quantity of their total produce being used for different purposes. From that the proportion of produce, used for different purposes by each respondent with respect of their individual production was 
calculated. Now to find the overall proportion of produce being utilized for different purposes by all the respondents, the means of their percentage of produce utilized for different purposes were considered. The collected data were tabulated and analyzed manually by using descriptive statistics i.e frequency and percentage.

\section{Results and Discussion}

The data, regarding the utilization pattern of annual produce of Khurasani by the Khurasani growers are presented in this segment.

\section{Utilization of the produce}

The results obtained after analysis of data about the utilization pattern of the produce are presented in the Table 1. It was observed that major proportion $(93.90 \%)$ of the produced
Khurasani was utilized for the oil extraction purpose. Oil of Khurasani contains medicinal properties and has long shelf life, was the reasons behind maximum quantity utilized for oil extractions.

A little amount (4.00\%) of the produce was used for the seed material as Khurasani requires very less quantity of seed for sowing purpose. Again they preserve small quantity of produce as planting material for next cropping season so that indigenous germplasm of Khurasani remain available with them. Utilization of the produce for home consumption purpose was the third area constituting only one per cent of total produce as people use to consume it occasionally as supplementary food. Less than one percent $(0.10 \%)$ of total produce was used for offering to relatives and friends.

Table.1 Utilization of produce by the respondents

\begin{tabular}{|c|l|c|}
\hline Sl. No. & \multicolumn{1}{|c|}{ Utilization area } & Percentage quantity of produce (\%) \\
\hline $\mathbf{1 .}$ & Seed & 04.00 \\
\hline $\mathbf{2 .}$ & Home & 01.00 \\
\hline $\mathbf{3 .}$ & Oil & 93.90 \\
\hline $\mathbf{4 .}$ & Offering & 00.10 \\
\hline
\end{tabular}

Table.2 Utilization of oil by the respondents

\begin{tabular}{|c|l|c|}
\hline S1. No. & \multicolumn{1}{|c|}{ Utilization area } & Percent of quantity of oil utilized (\%) \\
\hline 1. & Home consumption & 52.50 \\
\hline 2. & Sale & 47.00 \\
\hline 3. & Offering & 00.50 \\
\hline
\end{tabular}

Table.3 Utilization of by-products

\begin{tabular}{|c|c|c|}
\hline S1. No. & Utilization area & Percent of quantity of by-products utilized (\%) \\
\hline 1. & Giving to mill owner & 79.34 \\
\hline 2. & feed own animals & 20.66 \\
\hline
\end{tabular}




\section{Utilization of oil extracted}

Data regarding utilization of extracted oil presented in Table 2 revealed that more than onehalf $(52.50 \%)$ quantity of extracted oil was utilized for home consumption purpose. As the oil has essential primary fatty acids, nutty taste and pleasant odour, it is widely used as edible oil in that area. Again antioxidant, antiparasitic and antirheumatic properties make it a great for massages to keep different skin infections away. Further, it was noticed that a little less than one-half (47.00 $\%)$ quantity of the extracted oil was sold in the market for income generation purpose. The oil is being sold @ Rs. 120-130/lit on an average basis which helps to earn good amount of revenue that can be used to meet various monitory requirements of the Khurasani growers. Very little quantity $(0.50 \%)$ of the oil was used for offering to relatives and friends to maintain social relationship.

\section{Utilization of by-products}

The information regarding the utilization of byproducts of Khurasani after oil extraction is presented in table 3. From the table it was found that more than three-fourth $(79.34 \%)$ of the respondents was handing over all the by-products after oil extraction to the mill owners, instead of paying processing charges of oil extraction. It is because most of them don't have proper processing facility to utilize the by-products. The remaining 20.66 per cent of the respondents used by-products as cattle feed and to manufacture oil cakes. The oil cake is again sold in market @ Rs. 15 to 20 per $\mathrm{kg}$.

In conclusion, the utilization pattern of khurasani crop by the tribal farmers of Palghar district, indicated that major share of the produce goes for oil extraction purpose. Morever extracted oil was used for various cooking as well as medicinal purposes. This is really a good sign of value addition khurasani crop by the tribal farmers, who are using their indigenous knowledge for harnessing the various benefits from that crop. Possibilities of making available home scale units for oil extraction need to be explored. To enhance the production more area need to be covered under production of this crop. There are possibilities to use the khurasani crop in more diversified areas like soap making, paint preparation, emulsions preparation, manufacturing of bird feed, snacks, condiments and other edible dishes, etc. So efforts need to be taken to couple the existing utilization pattern of khurasani along with the manufacturing of various industrial commodities.

\section{Acknowledgement}

This research was supported by ICAR. I would like to show my gratitude to my advisor Dr. Hardikar sir and colleagues from College of Agriculture Dapoli, who provided insight and expertise that greatly assisted the research. I thank to Mr. Himadri Roy and Miss. Neha Kale for comments that greatly improved the manuscript andI also thank to reviewers for their so-called insights.

\section{References}

Anonymous 2011. Directorate of economics and statistics, Department of Agriculture and Cooperation, Ministry of Agriculture, GOI.

Burnette, R. 2010. 'The recent introduction of Niger seed. Production in northern Thailand.' ECHO Asia Notes, A Regional Supplement to ECHO Development Notes.

Talathi, M. S. Patil B. P. Khadse R. R. Chavan S. A. and Zagade M. V. 2007, Effect of sowing time, method of sowing and seed rate on yield and oil quality of Niger (Guizotia abysinica). Journal of Agromet. 9(1): 104-107.

\section{How to cite this article:}

Rohit Shelar, Himadri Roy, Neha Kale and Hardikar, D.P. 2018. Utilization Pattern of Khurasani Crop (Guizotia abyssinica) by the Khurasani Growers of Palghar District of Maharashtra, India. Int.J.Curr.Microbiol.App.Sci. 7(08): 1835-1838. doi: https://doi.org/10.20546/ijcmas.2018.708.210 